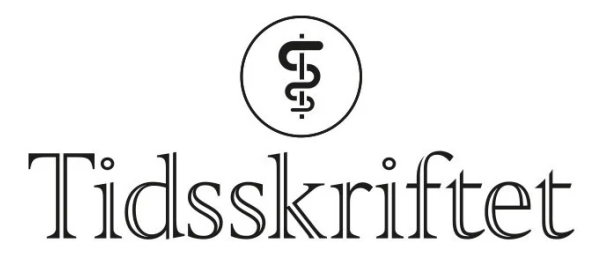

DEN NORSKE LEGEFORENING

\title{
På høring: Antibiotikabehandling ved sepsis
}

DEBATT

\section{TORGUN WAEHRE}

twaehre@ous-hf.no

Torgun Wæhre er ph.d., spesialist i indremedisin og i infeksjonssykdommer. Hun er seksjonsleder ved Infeksjonsmedisinsk avdeling, Oslo universitetssykehus, Ullevål, medlem av redaksjonen for oppdatering av Nasjonal faglig retningslinje for antibiotikabruk i sykehus og har ledet arbeidet med oppdatering av sepsiskapittelet.

Forfatteren har fylt ut ICMJE-skjemaet og oppgir ingen interessekonflikter.

\section{BJ $\varnothing$ RN WAAGSB $\varnothing$}

Bjørn Waagsbø er spesialist i indremedisin og i infeksjonssykdommer og overlege ved Regionalt kompetansesenter for smittevern, Helse Midt-Norge, leder av antibiotikateamet ved St. Olavs hospital samt medlem av redaksjonen for oppdatering av Nasjonal faglig retningslinje for antibiotikabruk i sykehus.

Forfatteren har fylt ut ICMJE-skjemaet og oppgir ingen interessekonflikter.

\section{STINA JORDAL}

Stina Jordal er spesialist $\mathrm{i}$ indremedisin og i infeksjonssykdommer og overlege ved Infeksjonsmedisinsk seksjon, Haukeland universitetssjukehus samt medlem av redaksjonen for oppdatering av Nasjonal faglig retningslinje for antibiotikabruk i sykehus. Forfatteren har fylt ut ICMJE-skjemaet og oppgir ingen interessekonflikter.

\section{EIRIK MÜLLER INDREB $\varnothing$}

Eirik Müller Indrebø er spesialist i indremedisin og i infeksjonssykdommer og overlege ved Infeksjonssykdommer, Akershus universitetssykehus samt medlem av redaksjonen for oppdatering av Nasjonal faglig retningslinje for antibiotikabruk i sykehus.

Forfatteren har fylt ut ICMJE-skjemaet og oppgir ingen interessekonflikter.

\section{HEGE WANG}

Hege Wang er ph.d., sivilingeniør. Hun er seniorrådgiver ved Avdeling retningslinjer og fagutvikling $\mathrm{i}$ Helsedirektoratet og prosjektleder for oppdateringen av Nasjonal faglig retningslinje for antibiotikabruk i sykehus.

Forfatteren har fylt ut ICMJE-skjemaet og oppgir ingen interessekonflikter.

\section{PER ESPEN AKSELSEN}

Per Espen Akselsen er spesialist i indremedisin, i infeksjonssykdommer og i geriatri. Han er overlege og faglig leder for Nasjonal kompetansetjeneste for antibiotikabruk i spesialisthelsetjenesten samt redaktør for oppdateringen av Nasjonal faglig retningslinje for antibiotikabruk i sykehus. 


\title{
Anbefalingene for antibiotikabehandling av sepsis diskuteres, særlig bruken av aminoglykosider. Utkast til reviderte anbefalinger er lagt ut til åpen høring.
}

\begin{abstract}
Nasjonal faglig retningslinje for antibiotikabruk i sykehus er under oppdatering (1) $)$. Så langt er åtte reviderte terapikapitler publisert. Kapittelet med anbefalinger for antibiotikabehandling ved sepsis og mistenkt sepsis er nå sendt på høring, med høringsfrist 28. februar 2022 for innspill til Helsedirektoratet (르).

Sepsis defineres etter sepsis-3-kriterier (3), som erstatter tidligere SIRS (Systemic Inflammatory Response Syndrome)-kriterier. I praksis vil mange pasienter ha «mistenkt sepsis», og disse pasientene er også inkludert i anbefalingene. Septisk sjokk er en undergruppe av sepsis karakterisert av hypotensjon til tross for væskebehandling, der man har behov for vasopressorbehandling. Anbefalingene vil ikke dekke alle kliniske sitasjoner, og i kompliserte tilfeller bør spesialist i infeksjonssykdommer kontaktes.
\end{abstract}

\section{Arbeidet bak nye retningslinjer}

Helsedirektoratet er utgiver av nasjonale faglige retningslinjer og er ansvarlig for metode, prosess og innhold. Fem spesialister i infeksjonssykdommer er oppnevnt som redaksjon for oppdateringen. Høringsutkastet er utarbeidet av redaksjonen i samarbeid med et bredt sammensatt fagnettverk bestående av spesialister i infeksjonssykdommer, anestesiologi og intensivmedisin samt mikrobiologer og en farmasøyt. Medlemmene i fagnettverket arbeider i åtte helseforetak, og alle fire helseregionene er representert.

Helsedirektoratets metode for utarbeiding av retningslinjer er kunnskapsbasert, noe som betyr at man i tillegg til evidensbasert kunnskap også vektlegger erfaringsbasert kunnskap og brukerkunnskap (når det er relevant). Videre er forekomst av antibiotikaresistens i Norge, og hvordan ulike antibiotika kan være drivere av antibiotikaresistens, en del av den kunnskapsbaserte tilnærmingen.

\section{Aminoglykosiders rolle i sepsisbehandling}

Som sepsisbehandling har kombinasjon av et smalspektret penicillin og et aminoglykosid lang tradisjon i Norge, men dokumentasjonen av effekt og bivirkninger er sparsom. Det er omdiskutert om aminoglykosider slik de brukes ved sepsisbehandling i Norge, gir vesentlig økt risiko for nyresvikt og andre organkomplikasjoner. Et stort flertall i fagnettverket ønsket å videreføre et behandlingsalternativ med aminoglykosid i mange av anbefalingene, med henvisning til erfaringsbasert kunnskap, norske resistensforhold og faren for økt bruk av bredspektrede betalaktamantibiotika hvis man fjerner dette alternativet. Fagnettverket har vært opptatt av å presisere hva som er rasjonell bruk av aminoglykosider og hvem som ikke bør ha det.

\section{Hva er nytt?}

I de nye anbefalingene for sepsisbehandling presiseres det at anbefalingene gjelder både for sepsis og mistanke om sepsis. Det er utarbeidet egne anbefalinger for septisk sjokk. For tilstandene septisk sjokk og sepsis med ukjent fokus har vi valgt å gi egne anbefalinger for henholdsvis samfunns- og sykehuservervet infeksjon. Begrunnelsen for dette er at 
pasientene er ulike med tanke på sannsynlig agens, risiko for antibiotikaresistens og risiko for nyresvikt. Anbefalingen om sepsis eller bakteriemi assosiert med intravaskulært kateter erstatter et tidligere kapittel om intravasalt kateter. Anbefalingen om sepsis når det er påvist bakteriemi med Staphylococcus aureus er ny.

«I de nye anbefalingene for sepsisbehandling presiseres det at anbefalingene gjelder både for sepsis og mistanke om sepsis»

I noen av anbefalingene har vi valgt å ikke sette opp ett spesifikt regime som standard, men heller oppgi alternativer og hos hvilke pasienter disse alternativene vil være aktuelle å bruke ut fra klinisk tilstand, risiko for nyresvikt, risiko for resistente mikrober (særlig ESBLholdige gramnegative stavbakterier), antibiotikaallergi med mer.

Tidlig antibiotikabehandling bedrer prognosen hos pasienter med sepsis, men tidsvinduet er omdiskutert. I samsvar med anerkjente internasjonale retningslinjer fra The Surviving Sepsis Campaign og Nederland har vi landet på å anbefale at antibiotika skal gis så raskt som mulig: innen én time hos pasienter med septisk sjokk og innen tre timer hos pasienter med sepsis eller mistenkt sepsis (4,5).

Antibiotikadoseringer er basert på Arbeidsgruppen for antibiotikaspørsmål og metoder for resistensbestemmelse (AFA) sitt grunnlag for norsk antibiotikadosering og andre kunnskapskilder, og gjelder oppstart av behandling hos pasienter med sepsis der sirkulasjon og distribusjonsvolum er påvirket (므). For mange klinikere vil dosene være uvant høye. Vi har presisert at dosene som regel kan reduseres når pasienten ikke lenger er septisk og man har påvist eventuelt agens.

\section{Høringsinnspill ønskes}

Det er faglig uenighet om de eksisterende anbefalingene for antibiotikabehandling av sepsis, særlig bruk av aminoglykosider, noe som tidligere har vært diskutert i Tidsskriftet (7-11). De reviderte anbefalingene legges derfor ut til en åpen høring med frist for innspill satt til 28. februar 2022.

\section{«Det er faglig uenighet om de eksisterende anbefalingene for antibiotikabehandling av sepsis, scerlig bruk av aminoglykosider»}

Helsedirektoratet, styringsgruppen for revisjonsprosjektet, redaksjonen for oppdateringen og et samlet fagnettverk for kapittelet om sepsis stiller seg bak utkastet til anbefalinger. Hensikten med høringen er å få innspill og synspunkter, både på om anbefalingene fremstår som hensiktsmessige og brukervennlige, og på antibiotikaregimer og øvrig informasjon.

\section{REFERENCES}

1. Nasjonal faglig retningslinje for bruk av antibiotika i sykehus. Oslo: Helsedirektoratet, 2013. https://www.helsedirektoratet.no/retningslinjer/antibiotika-i-sykehus Lest 28.1.2022.

2. Helsedirektoratet. Høringsutkast sepsis. https://www.helsedirektoratet.no/horinger/nasjonalfaglig-retningslinje-for-antibiotika-i-sykehus-sepsisanbefalinger Lest 28.1.2022.

3. Singer M, Deutschman CS, Seymour CW et al. The Third International Consensus Definitions for Sepsis and Septic Shock (Sepsis-3). JAMA 2016; 315: 801-10. [PubMed][CrossRef]

4. Evans L, Rhodes A, Alhazzani W et al. Surviving sepsis campaign: international guidelines for management of sepsis and septic shock 2021. Crit Care Med 2021; 49: 1063-143. [CrossRef] 
5. SWAB. The Dutch Working Party on Antibiotic Policy (SWAB) guideline for empirical antibacterial therapy of sepsis in adults. https://swab.nl/en/swab-guidelines Lest 28.1.2022.

6. Arbeidsgruppen for antibiotikaspørsmål og metoder for resistensbestemmelse. AFAs grunnlag for norsk antibiotikadosering. 2021. https://unn.no/Documents/Kompetansetjenester,\%20sentre\%2oog\%2ofagr\% $3 \%$ A 5 d/AFA\%2O-

\%2oarbeidsgruppen\%2ofor\%2oantibiotikasp\%C3\%B8rsm\%C3\%A51/AFAs\%2ogrunnlag\%2ofor\%2onorsk\%2 oantibiotikadosering\%202021.pdf Lest 28.1.2022.

7. Nordøy I, Laake JH. Uforsvarlige retningslinjer for antibiotikabruk i sykehus. Tidsskr Nor Legeforen 2013; 133: 1056. [PubMed][CrossRef]

8. Haug JB, Berild D, Blomberg B et al. Aminoglykosider ved alvorlig sepsis. Tidsskr Nor Legeforen 2013; 133: 1553-4. [PubMed][CrossRef]

9. Skrede S, Nygård ST, Langeland N et al. Aminoglykosider kan redusere risiko. Tidsskr Nor Legeforen 2013; 133: 1554. [PubMed][CrossRef]

10. Laake JH, Nordøy I. J.H. Laake \& I. Nordøy svarer. Tidsskr Nor Legeforen 2013; 133: 1555. [PubMed] [CrossRef]

11. Lindemann PC, Haldorsen BC, Smith I et al. Aminoglykosider bør fortsatt brukes i empirisk sepsisbehandling. Tidsskr Nor Legeforen 2013; 133: 1054-5. [PubMed][CrossRef]

Publisert: 3. februar 2022. Tidsskr Nor Legeforen. DOI: 10.4045/tidsskr.22.0029

Mottatt 10.1.2021, godkjent 28.1.2022.

(C) Tidsskrift for Den norske legeforening 2023. Lastet ned fra tidsskriftet.no 26. april 2023. 